\title{
ÚJ ANYAGOK ALKALMAZÁSÁNAK MEGBÍZHATÓSÁGI KÉRDÉSEI A JÁRMUUIPARBAN
}

\section{RELIABILITY QUESTION OF NEW MATERIAL USED IN VEHICLE ENGINEERING}

\author{
Trabelsi Omar, ${ }^{1}$ Tóth László ${ }^{2}$ \\ ${ }^{1}$ Óbudai Egyetem, Doktori Biztonságtechnikai Kar, Budapest, Magyarország, omar.trabelsi@uni-obuda.hu \\ 2 Óbudai Egyetem, Bánki Donát Gépész és Biztonságtechnikai Mérnöki Kar, Budapest, Magyarország, \\ toth.laszlo@bgk.uni-obuda.hu
}

\begin{abstract}
In-vehicle engineering, several types of materials can be used to build vehicles of different sizes and for different uses. Traditionally those materials can be iron, aluminium, steel, rubber, glass, copper, leather, and others. These materials have been in constant development over the years, and this development has accelerated during the last ten years as manufacturers strive to compete on the issue of reliability of these new innovative materials. Reliability requires the production of materials with minimal (or well-known) variations in properties or dimensions. Parts made from these materials must be manufactured using processes that have also been proven to be reliable. This aim of this paper is to explain how reliability criteria can only be obtained if there are means of control suited to the most used materials (metals and polymers).
\end{abstract}

Keywords: reliability, automotive manufacture, vehicle engineering, metals.

\section{Összefoglalás}

A járműgépészetben sokféle anyag használható fel a különböző méretű és típusú járművek gyártásához. Hagyományosan ezen anyagok az alumínium, acél, gumi, üveg, réz, bőr és egyebek. Ezek az anyagok folyamatosan fejlődnek, sőt ez a fejlődés felgyorsult, ahogy a gyártók, az elmúlt tíz évben, az új fejlett anyagok megbízhatósága problémájának megoldásán versenyeztek. A megbízhatóság megköveteli a megfelelő alapanyaggyártást, minimális tulajdonság és méretbeli változások mellett. Ezen új anyagokból készült alkatrészek szintén megbízhatónak mutatkoztak. Ez a munka azt hivatott bemutatni, hogy a megbízhatósági kritérium csak akkor érhető el, ha a figyelem a leginkább felhasznált anyagokra (fémekre és műanyagokra) irányul.

Kulcsszavak: megbízhatóság, autógyártás, jármügépészet, fémek.

\section{Bevezetés}

Az autógyártás az építőanyagok egyik legnagyobb felhasználója a világon [1-5].

A jármű megbízhatósága a felhasznált anyagokra koncentrál. Manapság járművek esetén a megbízhatóság kérdése a legfontosabb, és a felhasználók nem fordítanak figyelmet arra, hogy ezek milyen anyagokból készülnek. Egy autó ezernyi alkatrészből épül fel, ezért ezek anyagának és működésének megismerése jelentős feladat. Amíg a fémek egy autó egészének 64\%-70\%-át teszik ki, addig a többi része számos más anyagból, műanyagból, üvegből, textilből, festékekből tevődik össze. Vannak már speciális autóipari képesítések is, amelyek az autóipari ágazatot jellemzik. Az alkatrészek szilárdságnak és megbízhatóságának növelése fontos anyagtudományi probléma. 


\section{Felhasznált anyagok és választott feltételek}

\subsection{Felhasznált anyagok}

Egy modern jármű elsősorban fémekből és műanyagokból készül, melyek azt nehézzé teszik. $\mathrm{Az}$ alkalmazott új anyagok számos előnyös tulajdonsággal rendelkeznek (könnyü, nagy energiaelnyelő képesség, korrózióállóság stb.) [6-10]. Az anyagok jelenlegi felhasználása az autóiparban még mindig változó. Fémes anyagok (acélok, öntöttvasak és alumíniumötvözetek) még mindig túlnyomóan jelen vannak az automobilok felépítésében a tömeggyártásban. Egy jármű súlyában nagyjából $64-70 \%$ fém van jelen. A súly 35\%-a acéllemezekből áll, 11\%-a acél gépelem-alkatrészek, 9\%-a öntöttvas, 9\% alumínium. A fennmaradó anyagokat lásd az 1. ábrán.

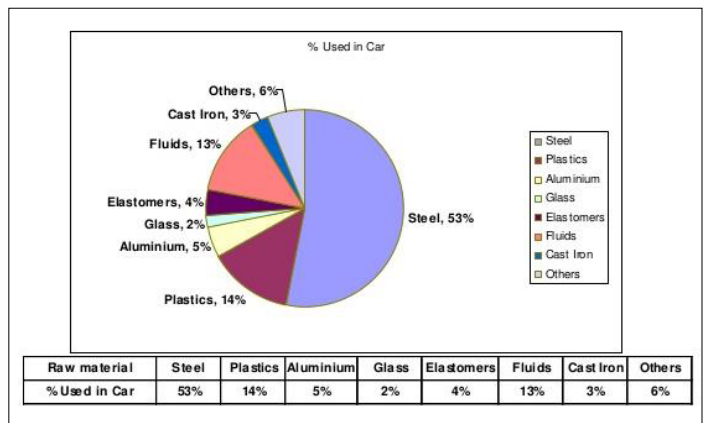

1. ábra. A tipikus jármüvekben található anyagok megoszlása

\subsubsection{Fémek}

Acél: Az acélipar és a beszállítók jelentős beruházásokat tettek a fejlődés érdekében. Ennek eredményeként számos új acél- és ötvözettípusok, illetve kémiai összetételek jelentek meg [11-12]: - kis szilárdságú acélok,

- hagyományos magas szilárdságú acélok (HSS), -ötvözött, magas szilárdságú acélok (HSLA), - képlékeny alakítással keményített, rugalmas acélok (TRIP),

- préseléssel edzett acélok (PHS).

Alumínium: Az utóbbi években az alumínium növekvő népszerűségnek örvend az autóiparban, a súly- és fogyasztáscsökkentés általános szükséglete miatt. Alumíniumötvözetet a vázszerkezetben és a terhelésviselő alkatrészekben használnak. Ezek megfelelnek az alábbi követelményeknek:

-megfelelő szilárdság (szerkezeti és élettartam-szilárdság, ütközésállóság),

-jó alakíthatóság (nyújtó, hajlító és mélyhúzó eljárások),

-összekapcsolhatóság (hegesztés, szegecselés, forrasztás, keményforrasztás) [13],

- magas korrózióállóság (stressz és kontaktkorrózióval szemben), nagy kopásállóság [14-16],

- újrahasznosíthatóság,

- alacsony előállítási költség.

Magnézium: A magnézium a legkönnyebb fém a maga $1,74 \mathrm{~g} / \mathrm{cm}^{3}$-es sürüségével (35\%-kal könynyebb az alumíniumnál, és több mint négyszer könnyebb az acélnál). Jó szívóssággal, hang- és rezgésállósággal rendelkezik, önthetősége kiváló.

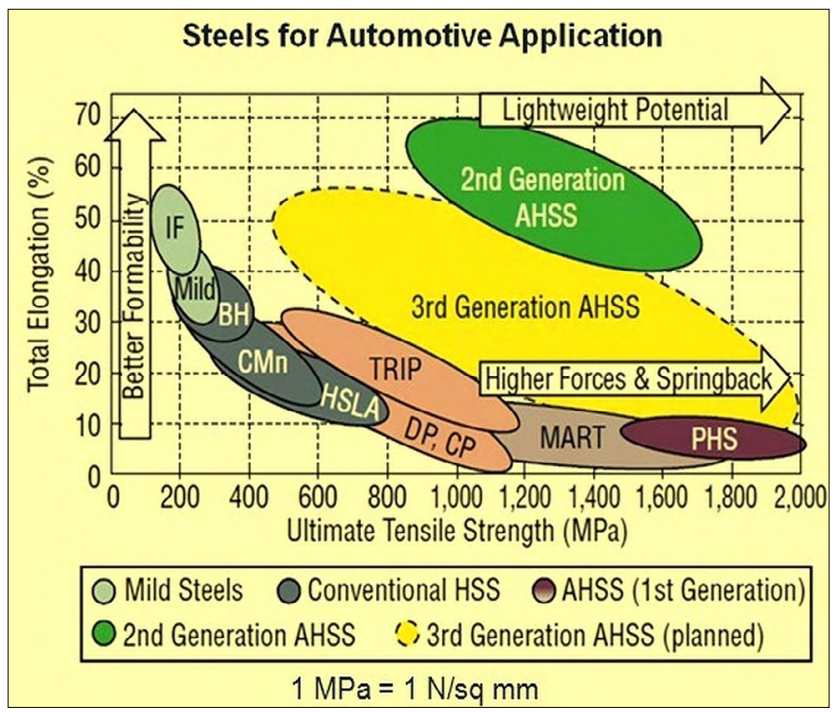

2. ábra. Az autóiparban használt acélok kategorizálása [1] 
A Volkswagen volt az első autóipari cég, amely magnéziumot használt a Beetle modell gyártásakor. Minden jármű 22 kg magnéziumot tartalmazott. Az egy jármühöz használt magnézium 2005 és 2015 között 3 kg-ról 50 kg-ra nőtt.

Titánium: A titánium felhasználása a nyolcvanas évek elején kezdődött az F1 versenyautók gyártásánál, a magas teljesítmény, gyors kanyarodás és irányíthatóság követelményeinek elérésére.

Titániumot használnak az autómotorban (Mitsubishi Galant), a felfüggesztésben (VW Lupo), a kipufogóban és a hangtompítókban (Kawasaki), a sebességváltókban (Honda S2000), a sárhányókban (Toyota Crown Majesta).

\subsubsection{Polimerek és kompozitok}

Polimerek: A polimer anyagok felhasználása folyamatosan nő, és ez az irányvonal várhatóan folytatódni fog. A polimer anyagokat az alkalmazhatóságuk, gazdaságosságuk és a fogyasztás csökkentése miatt alkalmazzák (a tömeg csökkentésével). A polimer anyagok szabadabb tervezést tesznek lehetővé, és sok esetben csak ezen anyagok nyújtanak biztonságos geometriai és gazdasági megoldásokat az alkatrészek előállítására.

Kompozitok: Kompozit anyagok jó tulajdonságú erősítőszálakból (pl. szén- és üvegszálak) és mátrixanyagokból (pl. epoxy gyanta) épülnek fel, amelyek együttesen jobb tulajdonságokkal rendelkeznek, mint önmagukban. A szénszál tömege közel egyötöde az acél tömegének, de mechanikai tulajdonságaiban éppolyan jó vagy jobb a merevség és szilárdság tekintetében. Továbbá nem rozsdásodnak vagy korrodálódnak az acéllal és alumíniummal szemben. A polimerekhez hasonlóan, kompozitokkal 60\%-kal könnyebb, biztonságosabb és üzemanyag-takarékosabb járműveket készíthetünk.

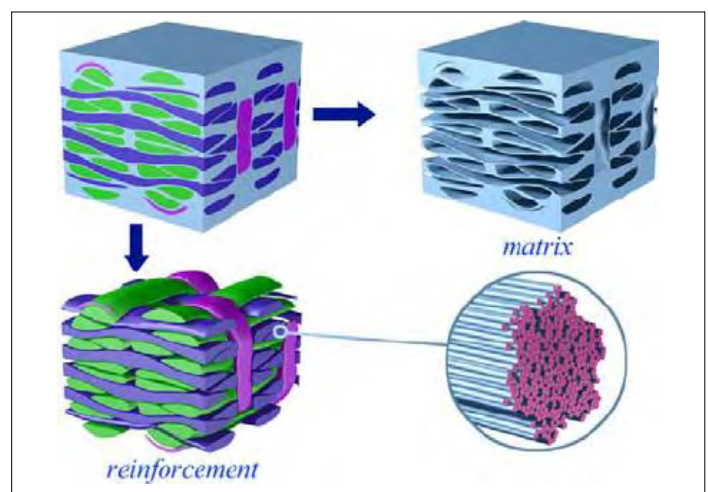

3. ábra. 3D szôtt kompozit anyagszerkezet, mezo- és mikronagyításban [8]

\subsection{Anyagválasztási kritériumok}

$\mathrm{Az}$ új, jobb jellemzőkkel rendelkező anyagok különböző okokból kerültek bevezetésre a jármügyártásban. Számos tényező áll a mérnökök rendelkezésére egy adott feladatot végrehajtó alkatrészcsoport alkotóanyagainak megválasztásakor. Valóban, egy alapanyagnak számos kritériumnak kell megfelelnie, mielőtt azt jóváhagynák mint megbízható alapanyagot.

A fejlesztési célok a következők:

-Biztonságosság: Ez egy szükséges követelmény, ami egyre szigorúbb vizsgálatokat jelent a jármüvek passzív biztonságának meghatározására (változó sebességek mellett). Ebben az esetben az anyagokat ellenálló képességük és különösen energiaelnyelő képességük szerint értékelik. A minőséget a megbízhatóságuk és tartósságuk adja meg.

- Kényelem: Az anyagok kihatással vannak a jármü rázkódására és zajára. A szerkezeti anyagok mechanikai tulajdonságainak helyes kihasználásával és hangelnyelő anyagok használatával befolyásolhatjuk az utasok kényelmét.

- Alacsony ár: Az anyagok és beépítésük ára természetesen alapvető. Ez gyakran megakadályozza a jó minőségű anyagok alkalmazását. Mindig figyelembe kell venni, hogy az autókat tömegtermelésben gyártják, és minden, az egy járművön megspórolt euró jelentős megtakarítást jelent.

-Környezettudatosság: Minimális fogyasztás: Gazdasági szempontból kényes terület a felhasználó számára, ugyanakkor fontos része a környezetvédelemnek. A károsanyag-kibocsátás mértékét egyre inkább szabályozzák az üvegházhatás csökkentése érdekében.

-2004 óta a $\mathrm{CO}_{2}$-kibocsátás 23\%-kal avagy $108 \mathrm{~g} / \mathrm{ml}-\mathrm{rel}$ csökkent, és az üzemanyag-gazdaságosság 30\%-kal, 5,8 mpg-vel nőtt. 2018-ban az üzemanyag-felhasználás gazdaságossága tovább növekedett 0,2 mérfölddel gallononként, 25,1 mpg-re, mely érték 2019-ben tetőzött. A becsült átlagos CO2-kibocsátás várhatóan $6 \mathrm{~g} / \mathrm{ml}-$ ről $346 \mathrm{~g} / \mathrm{ml}$-re fog csökkenni, míg az üzemanyag gazdaságossága 0,4 mpg-ről 25,5 mpg-re nő. -Új anyagok fejlődése (megbízható anyagok egy megbízható járműhöz).

A gyakorlati követelmények elérése érdekében szükségszerűvé válik az anyagok tesztelése, ellenőrzése és képességeik érvényesítése. A teszteknek, minőségi és biztonsági ellenőrzések eredményeinek meg kell felelniük a törvényeknek, a közlekedési szabályzatoknak, éppúgy, mint a fel- 
használó szükségleteinek: képesítés, teljesítmény, passzív értékelés, éles értékelés, szabványos minőségi ellenőrzés, korróziós teszt, kémiai analízis, elektronikus és elektromos tulajdonságok.

\subsection{Esettanulmány: ASTM autóipari anyag szabványok}

Az ASTM Internationalt, amelyet 1898-ban alapítottak, korábban úgy ismerték, mint az Amerikai Anyag és Anyagvizsgálati Testületet (American Society for Testing and Materials). Ez egy nemzetközi szabványszervezet, amely önkéntes konszenzusos, műszaki szabványokat jelentet meg az anyagok széles skálájáról, termékekről, rendszerekről és szolgáltatásokról. A szervezet segít javítani az általunk használt járművek minőségét, biztonságosságát és teljesítőképességét. Az ipari ellátóláncon keresztül ASTM-szabványok segítik a magas minőségű, szakszerűen ellenőrzött alkatrészeket és anyagokat az autógyárak számára. ASTM-szabványok erősítik a vásárlók bizalmát, biztosítva őket arról, hogy a vásárolt jármű strapabíró, megbízható. Az úton, ahol a jármű megbízhatósága a legfontosabb, a szabványok garantálják ezt.

Az ASTM legfontosabb szabványai az autóipari anyagok megbízhatóságára vonatkoznak. Ezek közül válogattunk példákat:

Szabványcsoport G03: Build Durable Autos19

A G03 több mint 30 szabványt tartalmaz, támogatást biztosítva ezzel az autóipari vállalkozóknak és beszállítóknak. A szabványok meghatározzák az autóipari festékek és bevonatok, valamint a műszerfalak anyagának műszaki jellemzőit, különböző természetes, szabadtéri időjárási viszonyok között. A G03-szabványok között találunk mechanikai tulajdonságokra vonatkozó szabványt, mely tartalmazza a nemfémes anyagok speciális ellenőrzési módszereit, mint a laborató-

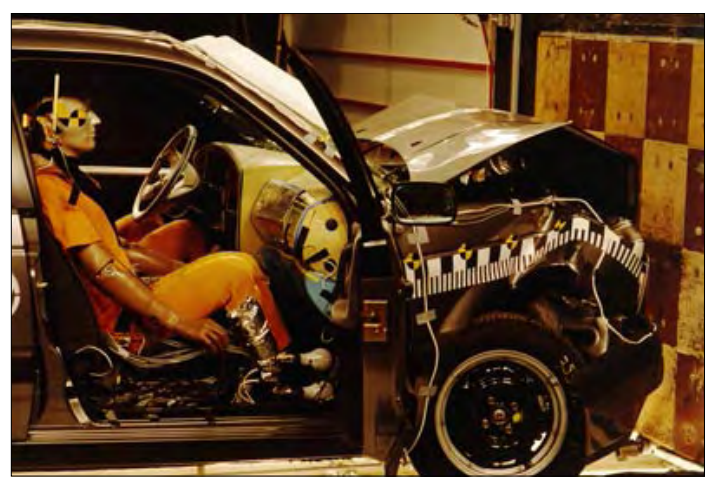

4. ábra. Autóütközés tesztje riumi fényforrásokkal gyorsított módszereket, UV fénykibocsátó berendezésekkel vagy fluoreszcens berendezésekkel. Mindezek a szabványok segítenek ellenőrizni az autóipari alkatrészeknek a napfény (akár közvetlenül, akár az ablaküvegen keresztül), a nedvesség, például eső vagy harmat, valamint a hő hatásainak való ellenálló képességét.

Szabványcsoport F16.02: Az acélcsavarokról, anyákról, szegecsekről és alátétekről

Tartalmazza, hogy milyen mechanikai tulajdonságokkal kell rendelkeznie ahhoz, hogy ellenálljon a dinamikus hatásoknak (ütközés), valamint azt, hogy miként vizsgálja az autóipari piacra szállított kötőelemek minőségét, szilárdságát és tartósságát. A gyártók a szabványra támaszkodnak. Az autóipari alkatrészekre számos szabvány vonatkozik még, köztük sok olyan, amelyekre a kötőelemek gyártói széles körben hivatkoznak.

Ezek közül említésre méltó a szénacél csavarok és csapok előírásai, pl. 420 MPa szakítószilárdság, valamint lefedi a szénacél csavarok és csapok mechanikai tulajdonságának követelményeit, $\Phi$ 1-15 mm közötti méretekben. Az autóipari beszállítók is alkalmazzák a hőkezelt acél szerkezeti csavarokra vonatkozó előírásokat, pl. a $830 \mathrm{MPa}$ minimális szakítószilárdság előírást, amely lefedi az oldható kötésekre való felhasználásra szánt hatlapú szerkezeti csavarok követelményeit.

Szabványcsoport D01.27: festés-bevonatolás.

Ez a csoport szabványokat ad az alkalmazott festék és a festékrendszerek tulajdonságainak értékelésére, normál és extrém környezetben, gyorsított vizsgálatoknak kitéve. Az autóipari bevonatok tartósságának javulása részben a gyorsított vizsgálati eljárás szabványcsoport alkalmazásának tulajdonítható. Általános gyakorlat az időjárási és korróziós vizsgálati eljárás a festett fém ciklikus só köd/UV-expozíciójának, amely ötvözi a ciklikus korróziótesztet a festékek ultraibolya expozíciójának értékelésével.

Az 5. ábrán a vizsgálatok eredményei láthatóak: a) 0 nap, b) 16 nap UV-expozíció, c) 0 nap UV fény 80 napos só köd után, és d) 16 nap UV sugárzás, majd 80 nap sóköd.

Szabványcsoport F09.30: Gumik szabványa különböző időjárási viszonyokra.

A laboratóriumi (nem gépjármű) tesztek személygépkocsik és könnyű teherautók radiál gumiabroncsainak gyorsított laboratóriumi vizsgálata az öregedésének vizsgálatára. A szabványok másik fontos csoportja a gumiabroncsok teljesítményének mérése kritikus időjárási viszonyok esetén. A gumiabroncsok hó- és jégfelületen történő 


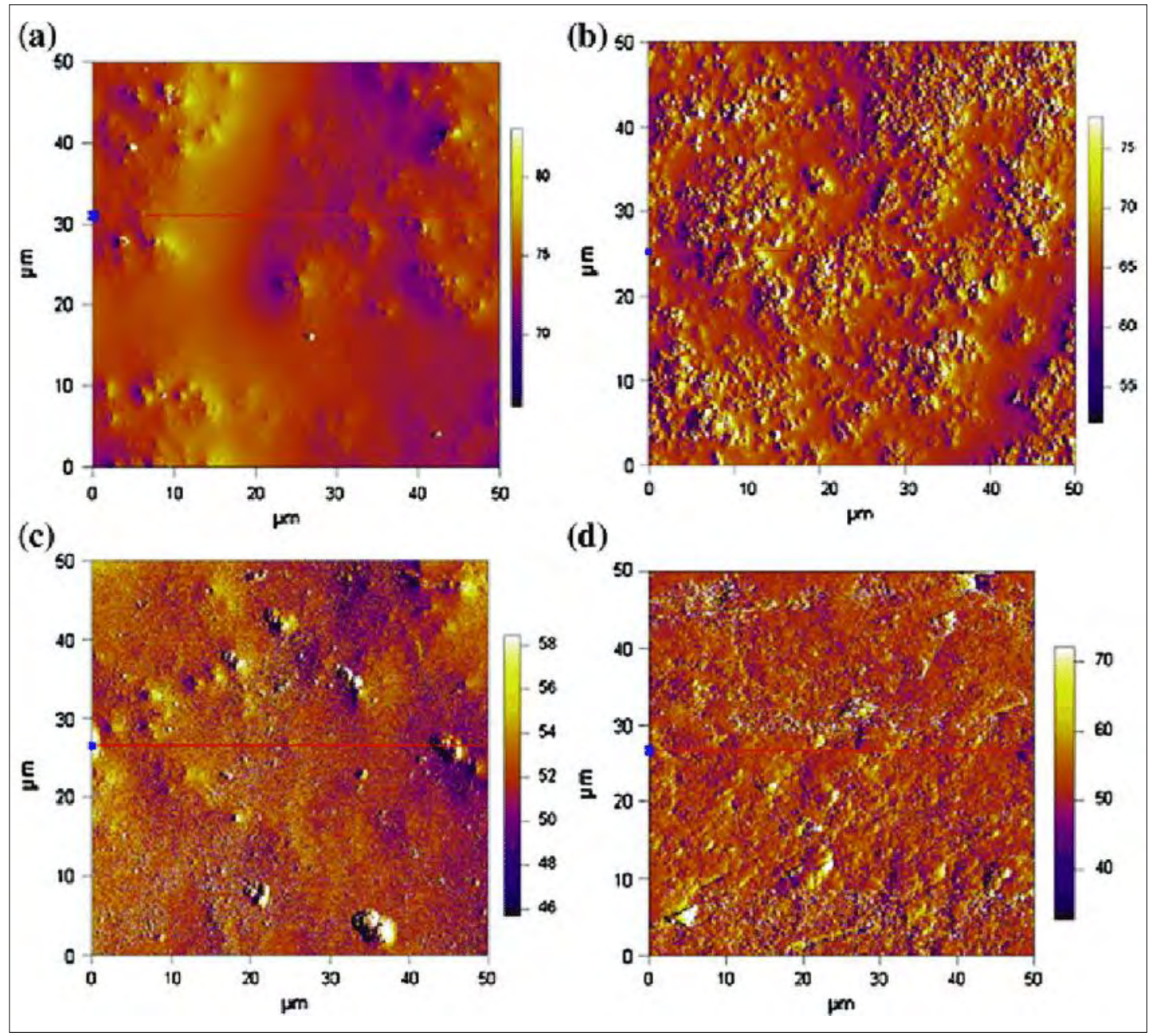

5. ábra. AFM felszíni képek, változó UV besugárzás és só köd tesztek mellett [7]

tesztelésének vizsgálati módszerei, valamint az egykerék egyenes vonalú tapadásának vizsgálata a hóval és jéggel borított felületeken, melyek segítenek felmérni a gumiabroncsok teljesítményét havon és jégen. Ezeket a vizsgálatok gyakran a P195/75R14 radiál referencia-gumiabroncson végzik, amelyet referenciaként használnak a gumiabroncs tapadási teljesítményének értékeléséhez.

Manapság sok gumiabroncsgyártó egy speciális piktogramot (csúcsos hegység hópehellyel) alkalmaz annak jelzésére, hogy termékeiken szabvány ajánlása szerint elismert tapadási teljesítményteszteket végeztek súlyos hó-, jég- és téli körülmények között (6. ábra).

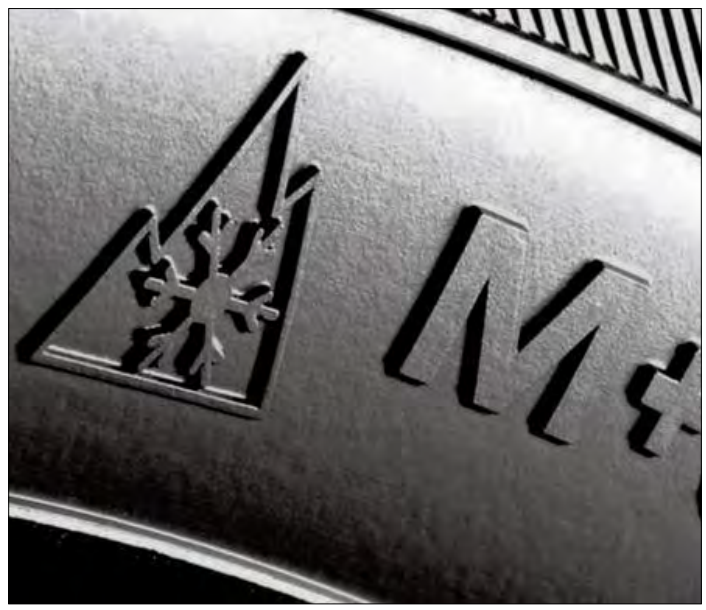

6. ábra. Three Peak Mountain Snowflake logó 


\section{Következtetések}

A termékek biztonságának és megbízhatóságának biztosításához a vizsgálati eljárások is folyamatosan fejlődnek. Ennek ellenére még mindig léteznek rések és technikai problémák, amelyek megoldást követelnek. Megállapítható, hogy az új, mai követelményeknek megfelelő anyagok fejlesztése (karbonbázisú vagy szerves anyagok) jelenthetnek megoldást. Emellett beszélni kell a jövőt jelentő könnyű súlyú anyagokról, különösképpen az első generációs repülő autók várható megjelenésével. Az új anyagok megbízhatósági kérdése a jövőben kiteljesedhet, nem csak az ipar számára, de a felhasználói oldalon is.

\section{Szakirodalmi hivatkozások}

[1] IspatGuru, Satyendra: Steels for automotive application, 2015.

https://www.ispatguru.com/steels-for-automotive-applications/

[2] Hirsch J.: Aluminium alloys for automotive application. Material Science Forum, 242. (1997) 33-50.

https://doi.org/10.4028/www.scientific.net/ MSF.242.33

[3] Friedrich H., Schumann S.: Research for a "new age of magnesium" in the automotive industry. Journal of Materials Processing Technology, 117/3. (2001) 276-281. https://doi.org/10.1016/S0924-0136(01)00780-4

[4] Yamashita Y., Takayama I., Fujii H., Yamazaki T.: Application and Features of Titanium for the $\mathrm{Au}$ tomotive Industry. Nippon steel technical report No.85 Special Issue on Titanium, January 2002.

[5] Maeder G.: Les nouveaux matériaux dans la mécanique automobile. Culture Technique, 25. (1992) 162-166. http://hdl.handle.net/2042/32752

[6] United States Environmental Protection Agency https://www.epa.gov/

[7] Andrady A. L.: Persistence of Plastic Litter in the Oceans. In: Marine Anthropogenic Litter. (Szerk.: Bergmann M., Gutow L., Klages M.) Springer, Cham, 2015, 57-72.

https://doi.org/10.1007/978-3-319-16510-3_3
[8] Drach A., Drach B.,Tsukrov I., Bayraktar H., Goering J.: Realistic FEA modeling of $3 D$ woven composites on mesoscale. 19th International Conference on Composite Materials (ICCM19), 2013.

[9] Kovács T. A., Nyikes Z., Figuli L.: Nagy energiaelnyelö képességü anyagok alkalmazása robbanás elleni védelemre/Development of a Composite $M a-$ terial for Impact Load. Acta Materialia Transylvanica, 2/2. (2019) 105-109. https://doi.org/10.33923/amt-2019-02-07

[10] Kovács T. A., Nyikes Z., Daruka N.: Critical Infrastructure Protection in the Historical Urban Region of Eastern European Countries. In. Security and Russian Threats (Szerk.: Banasik M.), Kielce, Lengyelország: The Jan Kochanowski University in Kielce - UJK, (2019), 151-158.,

[11] Kovács T. A., Mhatre U., Nyikes Z., Bitay E.: Surface Modification Innovation for Wear Resistance Increasing. IOP Conference Series: Materials Science and Engineering, 613012039 (2019). https://doi.org/10.1088/1757-899X/613/1/012039

[12] Béres G., Danyi, J., Végvári F., Tisza M.: Napjaink jármükarosszéria anyagai. Gradus 2/2. (2015) 209-224.

[13] Kovács T. A., Tóth L. Nyikes Z.: Robots Application for Welding. Müszaki Tudományos Közlemények, 12. (2020) 50-54.

https://doi.org/10.33894/mtk-2020.12.07

[14] Haraszti F., Kovács T.: Plastic deformation effect of the corrosion resistance in case of austenitic stainless steel. IOP Conference Series: Materials Science and Engineering, 175012048 (2017). https://doi.org/10.1088/1757-899X/175/1/012048

[15] Kovács-Coskun T., Bitay E.: The hardness control in the coated surface layer. Materials Science Forum, 729. (2013) 415-418.

https://doi.org/10.4028/www.scientific.net/ MSF.729.415

[16] Kovács T., Dévényi L.: Investigation of wear process by a gradient method. Materials Science Forum, 473-474. (2005) 213-218. https://doi.org/10.4028/www.scientific.net/ MSF.473-474.213 